\title{
Thomas Eger, Stefan Oeter, Stefan Voigt (eds.): Economic analysis of international law
}

\section{Tübingen: Mohr Siebeck, 2014}

\author{
Jürgen G. Backhaus
}

Published online: 1 October 2014

(C) Springer Science+Business Media New York 2014

Originally started by Claus Ott and Hans-Bernd Schäfer, the 13th Travemünde Symposion on the Economic Analysis of Law was held in March 2012 and for the first time in English. The late Christian Kirchner, himself both economist and lawyer, was one of the participants.

Not only the language, also the persons have changed; the next generation includes Thomas Eger and Stefan Voigt. In this case, they added Stefan Oeter who holds the chair in Comparative Public Law and Public International Law at the University of Hamburg. Since customary international law is not legislated, his question on the legitimacy of customary international law is certainly well taken. Likewise, Stefan Voigt deals with the economics of informal international law, Haksoo Ko writes on law and technology of data privacy, and Thilo Marauhn on private military contractors. Also highly interesting is Birgit Feldmann's article on fighting maritime piracy and then, of course, Florian Jeßberger and Julia Geneuss' reflections on the first 10 years of the international criminal court. Finally, Christian Kirchner in his usual, slightly humorous style treats us through the European constitutional impossibility theorem.

The book is carefully published, has an in-depth index and a very extensive set of biographies. At 79 euros, its price cannot be considered exaggerated.

\footnotetext{
J. G. Backhaus ( $₫)$

University of Erfurt, Erfurt, Germany

e-mail: juergen.backhaus@uni-erfurt.de
} 